\title{
Minimization of Fungicidal Applications Against Potato Late Blight in the North Caucasian Region: Use of the "Agrodozor" System
}

\section{A V Filippov, M A Kuznetsova, O I lakusheva, A N Rogozhin, N V Statsyuk, V N Demidova, and K V Borovsky}

Department of Potato \& Vegetable Diseases, All-Russian Research Institute of Phytopathology, Bolshie Vyazemy, Russia

\section{Abstract}

Late blight is considered to be the most devastating potato disease, which control requires application of fungicides able to significantly contaminate the environment and accumulate in agricultural products. Pesticide load on potato fields can be reduced via optimization of the scheme of protective treatments. Such optimization can be performed using a mathematical simulator describing the dependence of

Corresponding Author:

A $\vee$ Filippov

alexey@vniif.ru

Received: 25 October 2019

Accepted: 15 November 2019

Published: 25 November 2019

Publishing services provided by Knowledge E

(c) A V Filippov et al. This article is distributed under the terms of the Creative Commons

Attribution License, which permits unrestricted use and redistribution provided that the original author and source are credited.

Selection and Peer-review under the responsibility of the AgroSMART 2019 Conference Committee.

\section{G OPEN ACCESS} late blight-caused yield losses on the weather data and an "Agrodozor" decision support system (DSS). The performed analysis of a situation in the regions of the North Caucasus allowed us to determine three zones differing in the disease harmfulness and characterized by potential yield losses at the level of $<10,10-20$, and $>20$ $\%$ and the probability of disease appearance in field during 30,77 , and $90 \%$ of seasons, respectively. Using the "Agrodozor" DSS, we calculated the optimum dates of fungicidal treatments for these zones and showed that, comparing to the commonly used routine scheme of treatments, the use of this DSS provides a significant reduction of the number of such treatments and, therefore, the corresponding costs for their arrangement, as well as reduction of the total toxicity index of the required protective measures.

Keywords: potato, late blight, pesticide load, zoning, "Agrodozor" DSS, toxicity index

\section{Introduction}

Late blight caused by the oomycete Phytophhtora infestans is the most economically important disease of potato causing significant yield losses because of the early destruction of leafy tops and rotting of infected tubers during storage.

Spraying of plants with fungicides is able to significantly reduce yield losses caused by the late blight development. In the case of top potato-producing countries, such as Belgium, Netherlands, and UK, the number of such treatments of potato fields may reach 12--16 times per a season [1]. At the same time, financial losses in potato production may 
be caused not only by yield losses, but also by costs for unnecessary applications of fungicides.

To date two main schemes of fungicidal treatments against late blight are used in Russia. The first one provides for the application of fungicides based on a personal experience of $f$ potato grower and his knowledge (often incomplete) about the disease and the fungicides used. The second scheme (routine scheme) includes regular fungicidal treatments with the time intervals between them corresponding to the duration of the efficient action of the fungicides used; these treatments are usually carried out every 7--10 days starting from the shoot appearance. The first scheme is used in the majority of potato-growing enterprises. In this case, farmers often start to apply fungicides after the appearance of late blight symptoms in the field and are limited by 2--3 sprayings per a season with large time intervals between them. In seasons with a weak late blight development, such treatment scheme allows farmers to obtain a quite good yield; however, in the case of a severe disease development, it can not provide a proper potato protection. The second scheme is traditionally used by large potato-producing companies growing potato for processing industry (production of chips, starch, etc.). Application of this scheme often results in excessive pesticide load, so the role of pesticides as toxicants and pollutants of the environment increases [2].

A possible negative influence of fungicides on the human health and environment, as well as a high cost of these chemicals force scientists to search for new environmentally safe strategies of fungicide use. The frequency of sprayings should be balanced with potential losses caused by the disease.

The level of the late blight development during a vegetation season, as well as its effect on yield losses depend on numerous factors, the most important of which is the weather. There are some studies dedicated to the climatic zoning of territories in accordance with the threat of the possible development of late blight epiphytoties [3--5].

The scheme of fungicidal applications can be optimized using so-called decision support systems, or DSSs [6, 7]. The authors of this study developed a computerized DSS "Agrodozor" (http://agrodozor.ru). Based on weather data, this DSS makes it possible to determine the optimal dates of fungicide applications during the season, as well as to choose fungicides, which are the most appropriate for the given weather conditions. Earlier we arranged long-term field experiments in the Moscow region, which demonstrated that the use of the proposed DSS provided the same level of suppression of the late blight development, as the use of the routine system of treatments [8]. 
The purpose of this study was an attempt to optimize in silico the application of fungicides on potato fields of the North Caucasus regions via their zoning by the threat of the late blight development and the use of the "Agrodozor" DSS.

\section{Methods and Materials}

The climatic zoning of the region by the frequency of late blight epiphytoties was carried out using the earlier developed mathematical simulator describing the connection between potato yield losses and meteorological conditions of a vegetation season [9]. The simulator is as follows:

$$
\begin{gathered}
\omega_{1}=0.8 \cdot(2.37+0.48 a+67 b) \text { if } a>8, \\
\omega_{2}=0.8 \cdot(0.95 a+0.02) \text { if } a \leq 8,
\end{gathered}
$$

where $\omega$ is potato yield losses caused by the late blight (\%), $a$ is the number of 5-day intervals with conditions, favorable for the re-infection of plants, determined for a period between the shoot appearance and top decay, and $b$ is the percentage of such periods during the period between the canopy closure and bud formation in relation to the total number of such periods during the whole season.

The 5-day interval is considered to be favorable for plant re-infection if $y_{1}<y_{2}$, where: $y_{1}=--32.47+0.75 x_{1}+0.41 x_{2}+0.41 x_{3}+0.27 x_{4}+0.74 x_{5}+0.30 x_{6}-0.07 x_{7}-0.16 x_{8}+$ $0.06 x_{9}+0.01 x_{10}+2.88 x_{11}+1.98 x_{12}+1.98 x_{13}+1.79 x_{14}+0.53 x_{15}$,

$y_{2}=--31.34+0.63 x_{1}+0.37 x_{2}+0.42 x_{3}+0.22 x_{4}+0.65 x_{5}+0.24 x_{6}-0.06 x_{7}-0.15 x_{8}$ $-0.13 x_{9}+0.15 x_{10}+4.88 x_{11}+3.55 x_{12}+3.34 x_{13}+2.50 x_{14}+2.29 x_{15}$,

$x_{1,2,3,4,5}$ and $x_{6,7,8,9,10}$ are the day and night temperatures $\left({ }^{\circ} \mathrm{C}\right)$ in the nearest five consecutive days, respectively, and $x_{11,12,13,14,15}$ are precipitations forecasted for the same five days.

The $a$ and $b$ values were calculated for July 1--22 and June 21 -- July 11, respectively.

This simulator provides a calculation of potential yield losses for mid-early potato cultivars susceptible to the late blight and grown in the absence of sprinkling irrigation.

The calculations were performed using archival meteorological data for the past 10 years (2009--2018) recorded at weather stations located on the territory of the studied regions of the North Caucasus. The data were downloaded in the form of XLS tables [10].

During the zoning of the late blight harmfulness we used average values of potato yield losses (\%) calculated for 10 years at each point of weather data collection using a 
QGIS software package. The standard package of this program includes an interpolation method called inverse distance weighting (IDW).

For each season, the optimal data of fungicidal treatments were calculated in a virtual mode using the "Agrodozor" DSS and taking into account that each next treatment is carried out at least 10 days after the previous one. In addition, an optimal fungicide type was determined for each calculated data of treatment. The used assortment of fungicides included three different tyoes: translaminar (Curzate R), systemic (Ridomil Gold $\mathrm{MC}$ ), and contact (Bravo). Translaminar fungucudes are used during the first stage of potato plant development (shoot appearance -- canopy closure), systemic fungicides are applied during the second stage (canopy closure -- flowering), and contact fungicides are used at the third stage (flowering -- harvesting). Data calculated by the "Agrodozor" DSS were compared with the data calculated for the routine scheme of treatment, i.e., potato treatments every 7 days using the following sequence: Curzate R -- Curzate R -- Ridomil Gold MC -- Ridomil Gold MC -- Bravo -- Bravo (6 treatments per a season). The example of such calculation of the dates for protective treatments is shown in Fig. 1.

Toxicity indices of the active substances of the chosen fungicides were determined using the following equation [2]:

$$
\mathrm{MATF}=0.5 \cdot \mathrm{AM}+\mathrm{CM}+\mathrm{ECO}+1.5 \cdot \mathrm{BiolPM}
$$

where MATF is a multi-attribute toxicity factor, AM is the acute mammal toxicity index, CM in a chronic mammal toxicity index, ECO is an ecological toxicity index (sum of avian, aquatic and small invertebrate subindex values), and BiolPM is a biointensive integrated pest management index.

The MATF value for a single treatment of potato with Curzate R, Ridomil Gold MC, or Bravo fungicide is equal to 80,302 , and 82 , respectively.

\section{Results}

The performed zoning resulted in the construction of the North Caucasus map divided into three zones differing in the volume of potential yield losses related to the late blight appearance and development (Fig. 2).

According to the performed zoning, different territories of the North Caucasus vary in the risk of the negative effect of the late blight on a potato yield.

The areas of the first (potential yield losses $>20 \%$ ), second (10--20\%), and third $(<10$ $\%)$ zones are equal to 10,13 , and $77 \%$ of the total area of the studied region. The most 
part of the Dagestan and Chechen Republic represent territories with a low $(<10 \%)$ risk of late blight-caused yield losses. Karachaevo-Cherkessia and Kabardino-Balkaria include all three zones, which occupy almost equal territories of these republics. The territory of North Ossetia was most favorable for the late blight development.

The performed retrospective analysis of weather data showed that conditions favorable for development of the pathogen on potato fields located in the first, second, and third zones occur in 90,77 , and $30 \%$ of seasons, respectively. Therefore, one can suppose that the routine scheme of protection (fungicidal sprayings every 7--10 days) actively used in advanced potato-producing companies can be justified only for the zones with a permanently high risk of a severe disease development. Protective treatments in the seasons (or periods within the season), which were unfavorable for the late blight development, may be unprofitable, since financial losses in agriculture may be caused by either disease-induced yield losses, or non-justified costs of protective treatments. At the same time, application of the automated DSS "Agrodozor" based on the weather data and various biotic and abiotic factors, influencing on the host and the pathogen, allows a user to minimize the costs of protective measures and to reduce pesticide load on the agrosystem without any yield losses.

During the online mode of functioning, the "Agrodozor" system forms two types of recommendations for a potato grower:

1. Is it necessary to treat a field with a fungicide?

2. If yes, then which preparation should be used?

With the help of this DSS used in a virtual mode and based on the weather data recorded at 17 weather stations, we calculated the optimum date of fungicidal treatments according to the method illustrated on Fig. 1.

Additionally, for each treatment the system determined the most appropriate fungicide among the assortment of preparations included into this study. Finally, the following indices were calculated: the average number of recommended plant treatments, average costs of protective treatments, and the averaged multi-attribute toxicity factor of such treatments. These indices were then compared with those calculated for the routine scheme of treatment. The results of these calculations are shown in Table 1.

The obtained data showed that, comparing to the routine protection scheme, the use of the "Agrodozor" DSS provided a 1.4--2x reduction of the number of fungicidal treatments, $1.4-5 \times$ reduction of the costs of protective treatments, and 1.3--5.5x reduction of the total toxicity of fungicidal treatments. In contrast to the routine scheme, the number of treatments per a season varied depending on the current level of the 


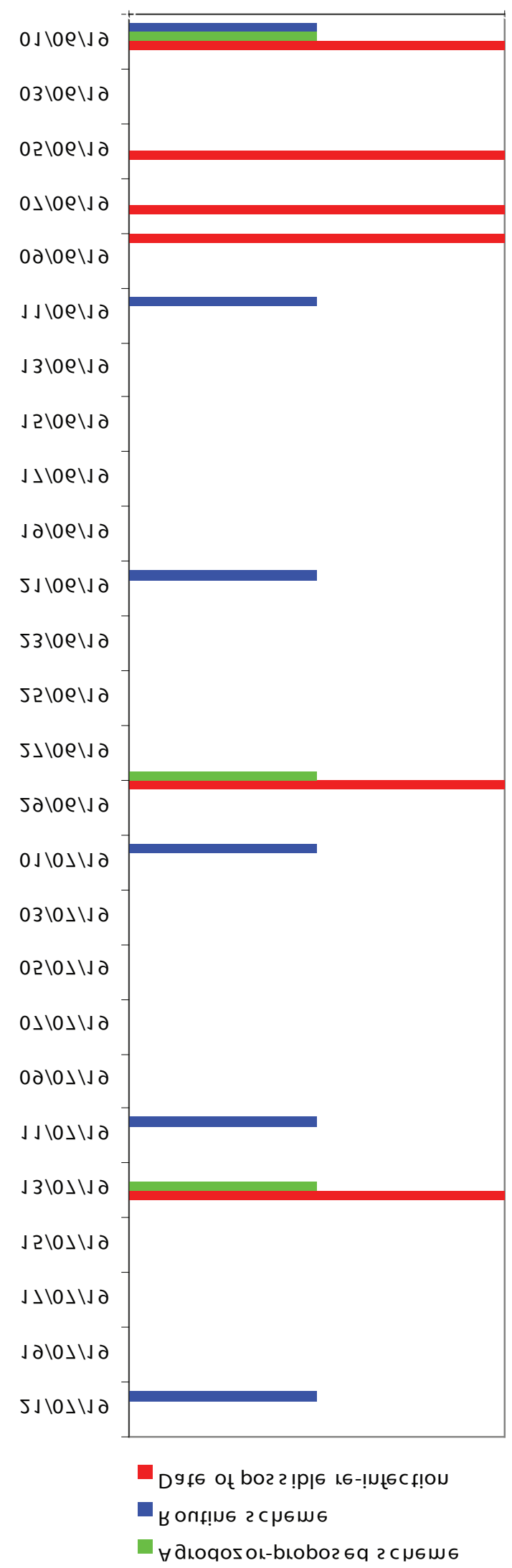

Figure 1: Example of the results of a calculation of dates for protective treatments of potato performed for the period of June-July of 2014 (weather station no. 37228, North Ossetia -- Alania). Fungicide designations: C, Curzate R; R, Ridomil Gold MC; B, Bravo. 


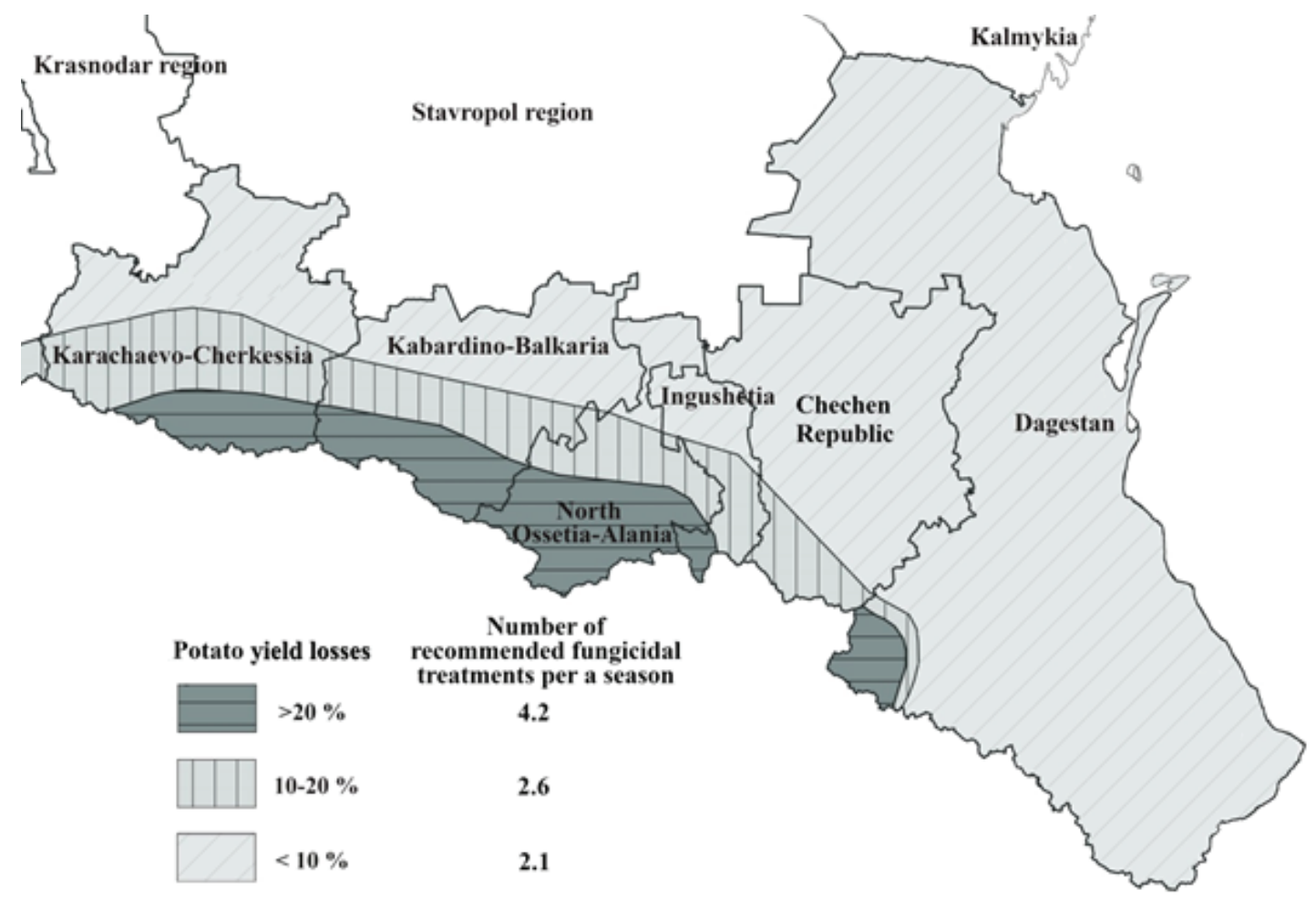

Figure 2: Zoning of the North Caucasian regions according to the potential harmfullmess of the late blight and the number of recommended fungicidal treatments of potato.

TABLE 1: Comparison of two schemes of fungicide application to control the late blight of potato.

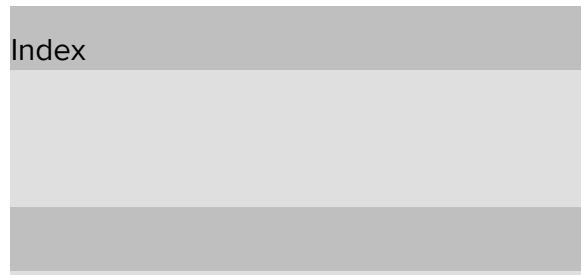

Average number of treatments per a season

Average cost of protective treatments, thousand roubles per a hectare ${ }^{2}$

Averaged multi-attribute toxicity factor

\begin{tabular}{|c|c|c|c|}
\hline \multicolumn{4}{|c|}{ Schemes of protective treatments ${ }^{1}$} \\
\hline \multicolumn{3}{|c|}{$\begin{array}{c}\text { Scheme recommended by the "Agrodozor" } \\
\text { DSS for the seasons with the following } \\
\text { potential yield losses: }\end{array}$} & \multirow[t]{2}{*}{$\begin{array}{l}\text { Routine } \\
\text { scheme }\end{array}$} \\
\hline$<10 \%$ & $10--20 \%$ & $>20 \%$ & \\
\hline 2.1 & 2.6 & 4.2 & 6 \\
\hline 8.0 & 10.0 & 16.0 & 23.0 \\
\hline 167 & 374 & 699 & 928 \\
\hline
\end{tabular}

${ }^{1}$ Routine scheme of treatment includes $2 \times$ treatment with Curzate R, $2 \times$ treatment with Ridomil Gold MC, and $2 \times$ treatment with Bravo; the interval between the treatments was 10 days. The treatment proposed by «Agrodozor" DSS is performed using the same preparations in the dates recommended by the system; the minimum interval between the treatments is 10 days (with allowance for the accepted sequence of treatments).

${ }^{2}$ The cost of a single treatment with the Curzate R, Ridomil Gold MC, and Bravo fungicides is 1500, 2000, and 1575 roubles/ha, respectively.

disease development: it reduced in the case of low forecasted yield losses ( $<10 \%)$ and increased to the maximum number, if the forecasted yield losses exceeded $20 \%$. 


\section{Conclusion}

In the case of a severe risk of the late blight development, a high yield of potato can be obtained only via multiple applications of fungicides. Moreover, the late blight causal agent, $P$. infestans, is the only pathogen, for which EU authorities approved the use of chemical (copper-based) fungicides even in the case of the organic agriculture [11]. Data obtained during this study give some grounds to suppose that the volume of the fungicidal treatments of potato may be significantly reduced using the developed zoning model and the "Agrodozor" DSS, i.e., this system may significantly improve the disease management practice not only on the North Caucasus, but also in other regions of Russia and the world.

\section{Acknowledgment}

This work was supported by the Governmental Program "Development of potato breeding and seed production in Russian Federation" (project "Monitoring and study of a potato late blight on the territory of Russia: mapping of regions by the threat of possible epidemics and the costs of protective fungicide treatments").

\section{References}

[1] Schepers, H., Hausladen, H., Hansen, J.G. et al. (2017). Epidemics and control of early and late blight, 2015 and 2016 in Europe. PAGV Spec. Rep., no. 18, pp. 11--32.

[2] Benbrook, C.M., Sexson, D.L., Wyman, J.A. et al. (2002). Developing a pesticide risk assessment tool to monitor progress in reducing reliance on high-risk pesticides. Am. J. Potato Res., vol. 79, pp. 183--199. DOI: 10.1007/BF02871934.

[3] Ustinova, O.K., Abashkina, E.V., Volvach, V.V. (1990). Dynamic model "weather yield 3 " for potato as a basis for the "potato -- pest (disease) -- environment" system. Trudy VNIISKhM, no. 26, pp. 93--96.

[4] Hijmans, R.J., Forbes, G.A., Walker, T.S. (2000) Estimating the global severity of potato late blight with GIS-linked disease forecast models. Plant Pathol., vol. 49, pp. 697--705. DOI: 10.1046/j.1365-3059.2000.00511.x.

[5] Grichanov, I.Y., Yakutkin, V.I., Ovsyannikova, E.I., Saulich, M.I. (2017). Maps of areas and zones of harmfulness of potato and sunflower pests and diseases. Vestnik zashchity rastenii (Supplement), no. 21, pp. 1--63. 
[6] Schepers, H.T.A.M. (2004). Decision support systems for integrated control of the late blight. Plant Breed. Seed Sci., vol. 50, pp. 57--62.

[7] Hu, T., Zhao, Z., Zhou, D., Zhu, J., Cao, K. (2014). Chemical control strategy of potato late blight based on the DSS "China-blight". PPO-Spec. Rep., no. 16, pp. 139--145.

[8] Filippov, A.V., Rogozhin, A.N., Kuznetsova, M.A., Smetanina, T.I., Demidova, V.N., Borovsky, K.V., Kononov, V.M. (2017). A new approach to the design of the VNIIFBlight decision support system used in the potato late blight and early blight management practice. PAGV-Spec. Rep., no. 18, pp. 67--76.

[9] Filippov, A., Kuznetsova, M., Rogozhin, A., lakusheva, O., Demidova, V., Statsyuk, N. (2018). Development and testing of a weather-based model to determine potential yield losses caused by potato late blight and optimize fungicide application. Front. Agr. Sci. Eng., vol. 5, pp. 462--468. DOI: 10.15302/J-FASE-2018239.

[10] Shaymardanov, V.M. (2011). Creation of databases of climate data and products for customer service. Proc. Rus. State Hydrometeorol. Univ., no. 17, pp. 89--98.

[11] Tschöpe, B., Kleinhenz, B., Keil, S., Zellner, M. Öko-SIMPHYT (= Organic-SIMPHYT): A forecasting system for specific scheduling of copper fungicides against late blight", PPO-Spec. Rep., no. 14, pp. 153--158. 